\title{
The Influence of Home and School Environments on Alcoholic Beverages, Tobacco and Marijuana Consumption by Adolescents in Prague and Brno
}

\author{
Irena Honsnejmanová $\mathrm{A}^{*}$, Jan Jarolímek ${ }^{\mathrm{B}}$ \\ Received: July 27, 2021 | Revised: October 27, 2021 | Accepted: November 08, 2021 \\ doi: 10.5937/gp25-33242
}

\begin{abstract}
Excessive use of alcoholic beverages, tobacco or marijuana is problematic not only for adults, but in some countries, it is a significant problem for children. However, the reasons for differences in children's risk behavior, as well as the reasons for risk behavior itself, are not yet fully understood. In this article we focused on the association between the quality of the school and home environment (and their surroundings) as perceived by children themselves and their risk behavior in relation to the use of selected substances. We worked with group of 3439 th grade primary school pupils in different types of neighborhoods. The results of our research show that at least some aspects of the quality of the physical environment have an impact on children's risk behavior.
\end{abstract}

Keywords: health risk behavior; school environment; family and individual factors; adolescence

\section{Introduction}

The quality of the environment we live in, as well as its individual person perception, has a significant influence on our health. Relations between environmental characteristics and risky behaviors are very complex and complicated. The growing interest in this topic has been reflected by lots of expert studies, not only medical, but also psychological, health-political or social-epidemiological ones. Also geographical studies focusing on the quality of the physical (built) environment and health have aroused public interest lately (Krieger \& Higgins, 2002; Handy et al., 2002; and others). As results of the studies show, the characteristics of the environment and living conditions in a particular area influence health and health behaviour of the population and may be related to their health-risk behaviors.
Poor physical and social environment aspects (home or school environments and their surroundings) are often topics of interest for experts in relation to health-risk behaviours of adolescents (Jang \& Johnson, 2001; Duncan, 2002; Galán et al., 2021). Addiction research confirms that early and intensive addictive substance abuse by adolescents leads to numerous physical, social and mental problems, not only during the adolescence but also later in the adulthood (Newcomb, 1997). Experts agree that it is not possible to focus only on studying home quality and the quality of social relationships in families, but also on school quality and environments (Leatherdale \& Manske, 2005; Reynolds et al., 2019). As for adolescents, it is just this case that school environments, relationships with classmates or social relationships are often as-

A Department of Geography, Faculty of Science, Masaryk University, Kotlářská 2, 61137 Brno, Czechia; honsnejmanova@mail.muni.cz

B Department of Social Geography and Regional Development, Faculty of Science, Charles University, Albertov 6, 12843 Prague 2; jarolija@natur.cuni.cz

* Corresponding author: Irena Honsnejmanová; e-mail: honsnejmanova@mail.muni.cz 
sociated with drug abuse (Hawkins et al., 1992; Ensminger et al., 2002; Spilková, 2015).

In this article, we have used the latest published data of the European School Survey Project on Alcohol and Other Drugs (ESPAD, 2020) and our own field research in the form of a survey questionnaire, which we carried out at selected schools in two biggest cities in Czechia Prague and Brno. We have tried to analyze some of the relations between the environment in which children and adolescents live and study and substance abuse in the context of the Pan-European ESPAD project's results. Our main goal was to find out whether and, if so, which aspects of the environment affect students the most. In our study, we have followed up on the first national study focusing on the influence of the physical environment, namely the types of housing developments, on health-risk behaviours of Prague adolescents (Dzúrová et al., 2015). This study has focused on studying risky behaviours of young people through the quality of their homes and school environments within several different types of housing developments in Prague. We have followed up on this pilot research, we further modified it and included the second largest city in the Czech Republic - Brno.

\section{Data and methods}

This study has used data that we collected from the survey questionnaire which was carried out in two largest Czech cities - Prague and Brno - between November 2018 and October 2019 using the Google Forms tool. There were two inclusion criteria for the research groups: 1) respondents were pupils of the 9th grade of primary schools, and 2) only two classes at one school could participate in the research. Questionnaires were filled in online by the 9th grade pupils from a total of 19 primary schools - 10 from Brno, 8 from Prague (one pupil did not report his/her school). There were two criteria for the school selection: 1) schools were selected according to the predominant type of housing developments while different types of housing developments were included approximately evenly, and 2) according to the locations in Prague and Brno (considering whether the schools were located on the outskirts or in the city centers).

The research was carried out after it had been presented to the principals of the selected schools (or prevention methodology or educational counselors) and after they had agreed to it. The participation in the research was voluntary and anonymous. Both factors were emphasized to the principals of the schools where the project took place, and also at the beginning of each questionnaire which were presented to pupils.

A total sample of 343 pupils filled in the questionnaire. At the time of the questionnaire completion, $54 \%$ of the pupils were 15 years old, $39 \%$ were 14 years old, $6 \%$ were 16 years old. 3 respondents reported ages that did not correspond to the ages of the 9th grade pupils, namely one respondent was 13 years old and two pupils were 17 years old, which was not clarified. Two students did not report their ages. The ratio of girls vs. boys was $53.4 \%$ vs. $46.6 \%$. Out of a total of 343 completed questionnaires, 186 were from Prague, 156 from Brno and in one questionnaire the question on the school location was missing.
There were 47 questions altogether in the questionnaire. The first part of the questionnaire focused on demographic issues such as age, gender, family financial situation (from the respondent's point of view), parents' education and the pupil's relationship with friends, parents and, if there are any, siblings. The second part of the questionnaire included questions focusing on who the respondent lived with, how he/she got to school, what he/she thought about the school and its environment and about his/her place of residence and its environment. The questionnaire was based on the Likert scale where respondents choose their answers from a predefined scale of answers. One of the key points of the questionnaire was the question on the types of housing developments in which the respondents' places of residence were located. In order to understand this question better, pupils were given six illustrative pictures with the names of residence categories (Fig. 1). They had to choose which of the pictures most closely resembled the place where they lived. They could choose from the following categories: block of flats, old city apartment house, new city apartment house, old detached house, new detached house and terraced house. The types of housing developments were selected with regard to the most common housing developments in Czech cities. Table 1 shows the percentage of the respondents by types of housing developments in their places of residence.

A total of $28.0 \%$ of respondents take usually $5 \mathrm{~min}$ utes to get to school, $40.2 \%$ of pupils take $6-15 \mathrm{~min}$ utes, $21.0 \%$ take $16-30$ minutes, $8.7 \%$ take $31-60 \mathrm{~min}$ utes and $2.0 \%$ of pupils take more than one hour to get to school. While in Brno $75.6 \%$ of pupils take 15 minutes to get to school, in Prague it is only $61.8 \%$. The big (but not surprising) difference between Prague and Brno is in the percentage of pupils who take more than half an hour to get to school - there are only 5.1\% of them in Brno and $15.6 \%$ in Prague. 


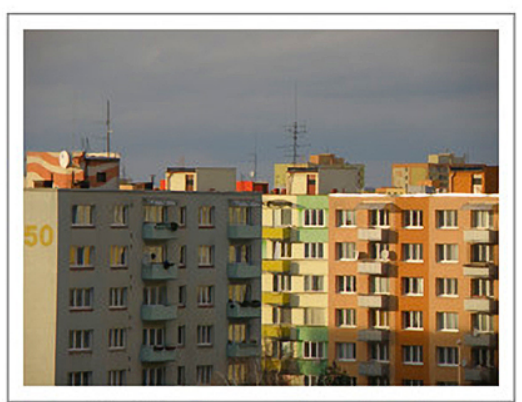

(1) Block of flats

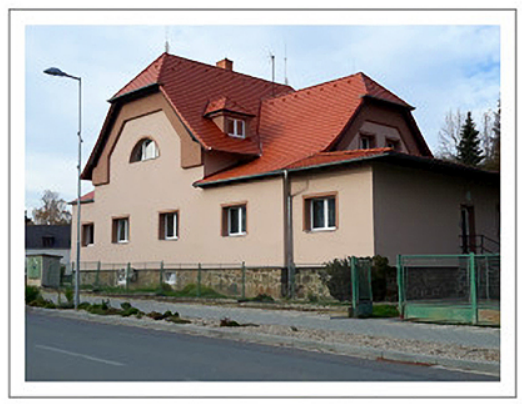

(4) Old detached house

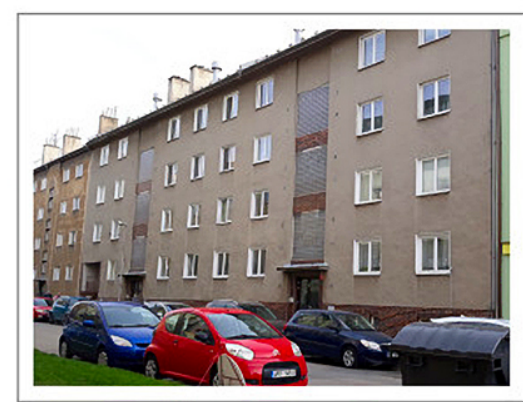

(2) Old city apartment house

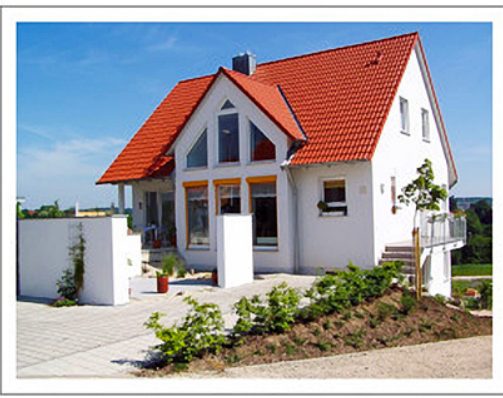

(5) New detached house

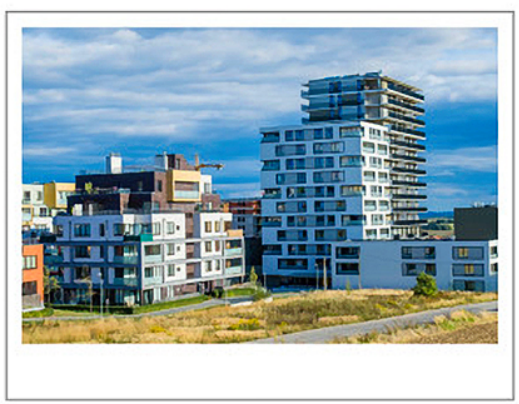

3 New city apartment house

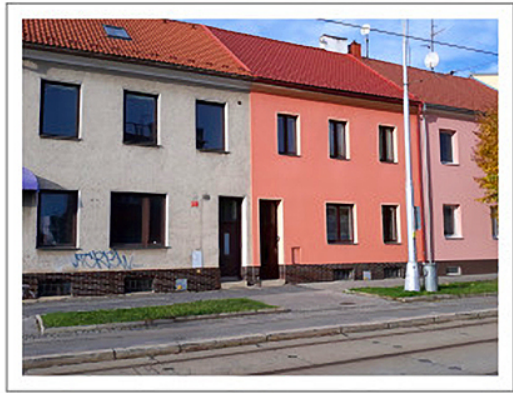

(6) Terraced house

Figure 1. Types of housing developments including survey pictures Source: Pictures 1, 3 and 5 - license CCO, pictures 2, 4 and 6 - author pictures

Table 1. Percentage of respondents based on types of housing developments at their places of residence

\begin{tabular}{|l|l|l|l|}
\hline Type of housing developments & Brno & Prague & Total \\
\hline New city apartment house & $9 . .6 \%$ & $8.1 \%$ & $8.7 \%$ \\
\hline New detached house & $11.5 \%$ & $23.1 \%$ & $17.8 \%$ \\
\hline Block of flats & $30.8 \%$ & $22.0 \%$ & $26.2 \%$ \\
\hline Terraced house & $20.5 \%$ & $9.1 \%$ & $14.3 \%$ \\
\hline Old city apartment house & $19.9 \%$ & $20.4 \%$ & $20.1 \%$ \\
\hline Old detached house & $7.7 \%$ & $17.2 \%$ & $12.8 \%$ \\
\hline
\end{tabular}

Note: Due to rounding, the sum does not add up to $100.0 \%$

Source: Own research

The following part of the questionnaire focused on the frequency and intensity of tobacco, alcoholic beverages and marijuana consumption by respondents and their closest relatives. The aim was not only to find out whether and to which extent pupils used selected substances, but also whether their consumption was affected or not by the consumption of the same substances by their close ones. For this reason, the question on how they got the substances was also included in the questionnaire. The last part of the questionnaire included questions on health and physical activities.

Concerning the families' financial situation, $58.3 \%$ of respondents answered that their financial situation is rather average, $27.1 \%$ of respondents reported their families as rather rich and $7.3 \%$ as very rich. A total of $6.7 \%$ of respondents think that their families' financial situation is not very good and only $0.6 \%$ of respondents think that it is not good at all. More than one quarter of pupils have parents with high school diplomas, $18.7 \%$ with university degrees, $14.9 \%$ have a father with a university degree and a mother with a high school diploma. $85.7 \%$ of respondents have siblings (including step-siblings).

Differences in the frequency of answers to the same questions in the questionnaire between a subgroup of pupils with no risky behaviours and a subgroup of pupils with at least one risky behaviours were evaluated using a chi-square test in a contingency table and expressed as Odds Ratio with a 95\% confidence interval. 


\section{Results}

In terms of risky behaviours, three risks were evaluated - (1) alcohol consumption, (2) smoking and (3) marijuana consumption. Before evaluating, it was first important to determine the extent to which the consumption of selected substances will be considered risky. In this respect, we relied on the WHO and SZÚ recommendations. Daily cigarette smoking (that is at least 1 cigarette per day) was considered risky tobacco consumption. As for alcohol, its consumption was considered risky if a pupil replied that he/she had drank 5 or more glasses of alcohol on at least three separate occasions in the last 30 days (one glass of alcohol means either 0.51 of beer, 0.21 of wine or 0.051 of spirits). Pupils who had used the substances at least 6 times in the last year were considered risky users of marijuana or hashish. We also found out how many types of risky behaviours were identified concerning a pupil - whether none, one, two or even all three types. We also found out the respondents' perception of the quality of the internal and external environments of their homes and schools they attended.

With a sample of 343 respondents who filled in the questionnaire, 273 respondents were considered with no risk of alcohol, tobacco or marijuana consumption, 70 respondents with at least one risky behaviour (of whom 39 only used one risky substance, 17 two and 14 three substances). In other words, about $20 \%$ of the pupils who filled in the questionnaire took at least one of risky substances. The most common were alcohol (46 pupils) and tobacco (40 pupils). We identified 29 students at-risk for marijuana consumption.

If we compare the number of high-risk substance users among pupils in Prague and Brno (Figure 3), the situation in the capital city is worse off. In Prague, we classify $15.1 \%$ of pupils as at-risk tobacco users, in Brno it is $7.7 \%$. The difference between the two cities is sta- tistically significant (OR 2.141, CI 1.050-4.368). 17.2\% of Prague pupils and $9.0 \%$ of Brno pupils consume alcohol at a risk level. This statistical difference is also significant (OR 2.122, CI 1.088-4.140). There is no big difference as for marijuana, $9.7 \%$ of respondents from Prague and $7.1 \%$ of respondents from Brno are among risky users. This difference is statistically insignificant.

As for pupils who attend schools in Prague, the situation is more serious in terms of the number of risky behaviours. Although the difference in the number of pupils based on the number of risky behaviours between Prague and Brno did not reach statistical significance, Figure 2 shows that in Prague the percentage of pupils with risky behaviours is higher than in Brno. Out of the total number of 186 respondents, 23 of them reported one risky behaviour, 11 of them reported two risky behaviours and 11 of them reported three risky behaviours. The questionnaire was filled in by 156 pupils from Brno schools, of whom we reported 16 with 1 risky behaviour, 6 with 2 risky behaviours and 3 with three risky behaviours.

Table 2 summarizes the percentage of respondents' risky behaviours based on types of housing developments. The most pupils with risky behaviours live in new detached houses. Risky users of all three types of substances are most common among inhabitants of new detached houses, $21.3 \%$ of the pupils living in this type of housing development are risky alcohol consumers, $18.0 \%$ of the pupils smoke cigarettes and $13.1 \%$ of the pupils use marijuana. The lowest number of the pupils with no risky behaviours is among the pupils who live in this type of house. On the other hand, among the pupils who live in terraced houses, there occur the least risky users of all types of the substances, there are also the most pupils with no risky behaviours at all and there were even no respondents with all three risky behaviours.

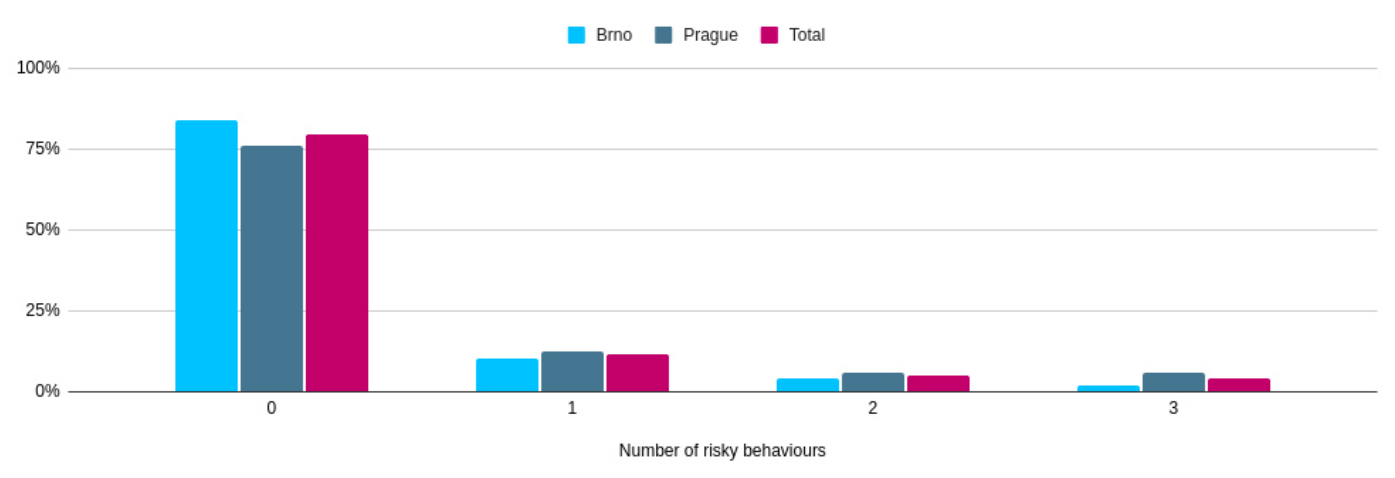

Figure 2. Percentage of pupils based on city categories and the amount of risky tobacco, alcohol and marijuana consumption

Note: The only pupil who did not report his/her place of residence did not behave risky and is included only in the "Total" column

Source: Own research 


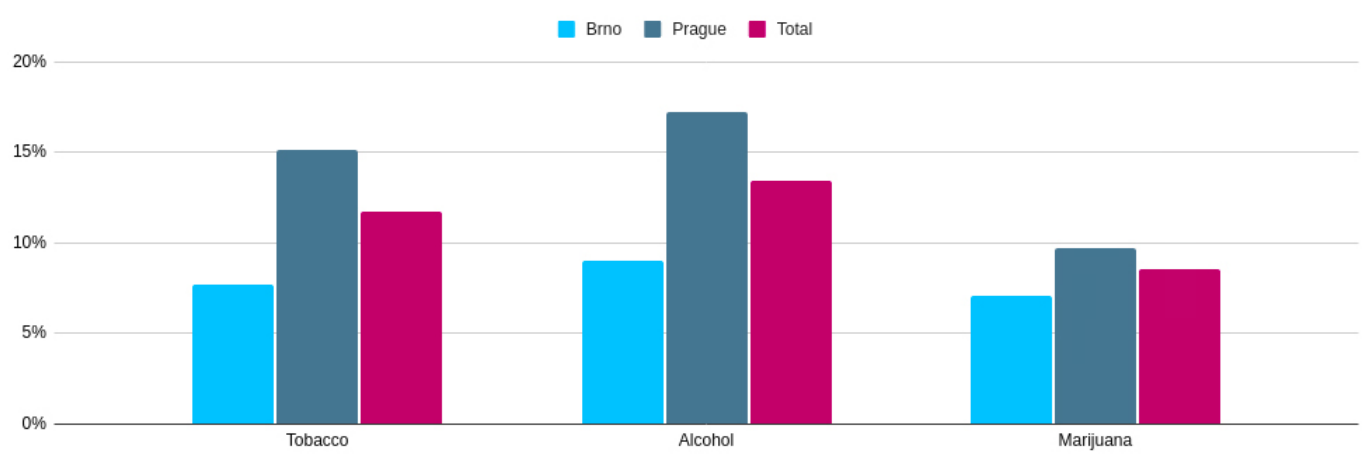

Figure 3. Percentage of respondents at-risk consuming tobacco, alcohol or marijuana Source: Own research

Table 2. Percentage of respondents at-risk consuming tobacco, alcohol or marijuana, based on types of housing development

\begin{tabular}{|l|c|c|c|c|c|c|c|}
\hline \multirow{2}{*}{} & \multirow{2}{*}{$\mathrm{N}=\mathbf{3 4 3}$} & \multicolumn{2}{|c|}{ Tobacco } & \multicolumn{2}{c|}{ Alcohol } & \multicolumn{2}{c|}{ Marijuana } \\
\cline { 3 - 8 } & & Abs. & $\mathbf{( \% )}$ & Abs. & $\mathbf{( \% )}$ & Abs. & (\%) \\
\hline New city apartment house & 30 & 3 & 10.0 & 5 & 16.7 & 3 & 10.0 \\
\hline New detached house & 61 & 11 & 18.0 & 13 & 21.3 & 8 & 13.1 \\
\hline Block of flats & 90 & 12 & 13.3 & 14 & 15.6 & 6 & 6.7 \\
\hline Terraced house & 49 & 1 & 2.0 & 3 & 6.1 & 3 & 6.1 \\
\hline Old city apartment house & 69 & 7 & 10.1 & 7 & 10.1 & 6 & 8.7 \\
\hline Old detached house & 44 & 6 & 13.6 & 4 & 9.1 & 3 & 6.8 \\
\hline
\end{tabular}

Source: Own research

The main aim of this study was to find out whether and, if so, how the risky use of selected addictive substances by primary school pupils is related to their places of residence and school attendance. We set a null hypothesis that at-risk alcohol, tobacco and marijuana consumption is not related to places of residence and places of school.

Pupils could choose from five different answers to the question "How do you like going to school?": I like very much, I like, I quite like, I dislike, I don't like at all. Table 3 summarizes results. We have found out statistically significant difference between subgroups of pupils with and with no risky behaviours in answers "I like" (OR 0.413, CI 0.188-0.907) and "I don't like at all" (OR 3.231, CI 1.497-6.971).
In other words, pupils who like going to school are less likely to use risky substances by $60 \%$ than other pupils. On the other hand, pupils who dislike going to school are more than three times likely to use risky substances than other pupils. The answer "I like very much" was only reported by pupils with no or one risky behaviours. Pupils living in new detached houses like going to school best. $32.8 \%$ of them replied to the question "How do you like going to school?" by choosing answers I like very much or I like, on the other hand, the smallest percentage of the same answers was reported by pupils living in old apartment houses (18.8\%).

The $93.4 \%$ of pupils living in new detached houses replied to the question "Do you think that the place

Table 3. Percentage of responses to the question "How do you like going to school?" of respondents with (at least one) and with no risky behaviours

\begin{tabular}{|l|c|c|c|}
\hline & $\begin{array}{c}\text { Pupils with (at least } \\
\text { one) risky behaviours } \\
\mathrm{N}=70\end{array}$ & $\begin{array}{c}\text { Pupils with no } \\
\text { risky behaviours } \\
\mathrm{N}=\mathbf{2 7 3}\end{array}$ & $\begin{array}{c}\text { OR } \\
(\mathbf{9 5 \%} \mathrm{Cl})\end{array}$ \\
\hline I like very much & $1 . .4 \%$ & $5.9 \%$ & $0.233(0.030-1.786)$ \\
\hline I like & $11.4 \%$ & $23.8 \%$ & $0.413(0.188-0.907)$ \\
\hline I quite like & $45.7 \%$ & $47.6 \%$ & $0.926(0.547-1.569)$ \\
\hline I dislike & $22.9 \%$ & $16.1 \%$ & $1.542(0.810-2.938)$ \\
\hline I don't like at all & $18.6 \%$ & $6.6 \%$ & $3.231(1.497-6.971)$ \\
\hline
\end{tabular}

Source: Own research 
you live is good to live?". Pupils living in new and old apartment houses are not very satisfied. However, the level of satisfaction is still high, about $77 \%$. We have found out a significant difference among groups of pupils with risky and with no risky behaviours in their answers to this question as "Yes, it is a very good place" and "It is quite a good place". These answers were reported mostly by pupils with no risky behaviours, on the contrary, the answer "Yes, it is a good place" was mostly reported by pupils with at least one risky behaviour. However, the statistical evaluation of the differences among pupils with risky and with no risky behaviours did not give a consistent result in terms of a biologically plausible gradient (Table 4 ).

Table 5 summarizes answers to the question whether pupils feel safe where they live, across categories based on the risk of substances consumption. Pupils who always feel safe where they live are about $50 \%$ less likely to use addictive substances, pupils who usually feel safe where they live are, on the contrary, about two times more likely to use addictive substances. The difference was not so statistically significant for the answers "sometimes" and "never".

Table 6 summarizes the results of responses to the question whether the respondents consider the select- ed facts in the surroundings of their places of residence as problematic. These facts include:

1. riots due to racial, ethnic or religious differences

2. mess, rubbish, broken glass in the streets, pavements, courtyards

3. drugs or excessive alcohol consumption

4. violence, vandalism and criminality

5. heavy traffic, traffic jams

6. abandoned and unmaintained properties in the surroundings

7. bad environment and lack of green spaces

8. lack of playgrounds and other sports grounds

Most pupils with no risky behaviours consider heavy traffic (31.5\%), drugs or excessive alcohol use (26.0\%) and mess (24.2\%) in the surroundings of their places of residence as highly or very problematic. $\mathrm{Pu}$ pils with at least one risky behaviour reported the same problems, but in a different order. The majority of pupils reported drugs (32.9\%), mess (30.0\%) and traffic (27.1\%) as the most negative issues. However, there was no statistically significant difference among answers to this question reported by pupils with and without risky behaviours.

Next, pupils had to aswer the question if they considered the selected facts (the same as in Table 6) in

Table 4. Percentage of responses to the question "Do you think that the place you live is good to live?" of respondents with and with no risky behaviours

\begin{tabular}{|l|c|c|c|}
\hline & $\begin{array}{c}\text { Pupils with (at least } \\
\text { one) risky behaviours } \\
\text { N=70 }\end{array}$ & $\begin{array}{c}\text { Pupils with no } \\
\text { risky behaviours } \\
\mathrm{N}=273\end{array}$ & $\begin{array}{c}\text { OR } \\
(95 \% \mathrm{Cl})\end{array}$ \\
\hline $\begin{array}{l}\text { Yes, it is a very good } \\
\text { place }\end{array}$ & $21 . .4 \%$ & $35.2 \%$ & $0.503(0.270-0.937)$ \\
\hline Yes, it is a good place & $65.7 \%$ & $48.0 \%$ & $2.078(1.201-3.593)$ \\
\hline $\begin{array}{l}\text { It is quite a good } \\
\text { place }\end{array}$ & $5.7 \%$ & $15.0 \%$ & $0.343(0.119-0.992)$ \\
\hline $\begin{array}{l}\text { It is not a very good } \\
\text { place }\end{array}$ & $4.3 \%$ & $0.7 \%$ & $\begin{array}{c}6.067(0.994- \\
37.039)\end{array}$ \\
\hline It is a bad place & $2.9 \%$ & $1.1 \%$ & $2.647(0.434-16.156)$ \\
\hline
\end{tabular}

Source: Own research

Table 5. Percentage of responses to the question "Do you feel safe where you live?" of respondents with and with no risky behaviours

\begin{tabular}{|l|c|c|c|}
\hline & $\begin{array}{c}\text { Pupils with (at } \\
\text { least one) risky } \\
\text { behaviours } \\
\mathrm{N}=70\end{array}$ & $\begin{array}{c}\text { Pupils with no risky } \\
\text { behaviours } \\
\mathrm{N}=273\end{array}$ & OR \\
\hline$(95 \% \mathrm{Cl})$ & $41 . .4 \%$ & $57.1 \%$ & $0.530(0.311-0.904)$ \\
\hline Always & $50.0 \%$ & $33.0 \%$ & $2.033(1.194-3.462)$ \\
\hline Usually & $7.1 \%$ & $8.4 \%$ & $0.836(0.306-2.284)$ \\
\hline Sometimes & $1.4 \%$ & $1.5 \%$ & $0.975(0.107-8.860)$ \\
\hline Rarely or never & & &
\end{tabular}

Source: Own research 
Table 6. Percentage of respondents who answered that they consider the following facts in the surroundings of their places of residence as highly or very problematic

\begin{tabular}{|l|c|c|c|}
\hline & $\begin{array}{c}\text { Pupils with (at least } \\
\text { one) risky behaviour }\end{array}$ & $\begin{array}{c}\text { Pupils with no risky } \\
\text { behaviours }\end{array}$ & OR (95\% CI) \\
\hline Riots due to racial, ethnic or religious differences & $8.6 \%$ & $14.7 \%$ & $0.546(0.222-1.345)$ \\
\hline $\begin{array}{l}\text { Mess, rubbish, broken glass in the streets, pavements, } \\
\text { courtyards }\end{array}$ & $30.0 \%$ & $24.2 \%$ & $1.344(0.751-2.404)$ \\
\hline Drugs or excessive alcohol consumption & $32.9 \%$ & $26.0 \%$ & $1.392(0.789-2.455)$ \\
\hline Violence, vandalism and criminality & $22.9 \%$ & $19.4 \%$ & $1.230(0.653-2.317)$ \\
\hline Heavy traffic, traffic jams & $27.1 \%$ & $31.5 \%$ & $0.810(0.451-1.455)$ \\
\hline $\begin{array}{l}\text { Abandoned and unmaintained properties in the } \\
\text { surroundings }\end{array}$ & $12.9 \%$ & $16.5 \%$ & $0.748(0.346-1.614)$ \\
\hline Bad environment and lack of green spaces & $17.1 \%$ & $21.6 \%$ & $0.750(0.378-1.489)$ \\
\hline Lack of playgrounds and other sports grounds & $14.3 \%$ & $14.3 \%$ & $1.000(0.472-2.118)$ \\
\hline
\end{tabular}

Source: Own research

the surroundings of their schools as highly or very problematic as well. Table 7 summarizes the results. A statistically significant difference between pupils with and without risky behaviours was reported regarding mess in the surroundings of their schools (OR 2.076, CI 1.221-3.532) and violence or vandalism (OR 2.094,
CI 1.215-3.609). Pupils who consider mess, rubbish, violence, vandalism and criminality in the surroundings of their schools as highly or very problematic are about two times more likely at-risk to consume alcohol, tobacco or marijuana. As for other questions, there were no significant differences.

Table 7. Percentage of respondents who answered that they consider the following facts in the surroundings of their schools as highly or very problematic

\begin{tabular}{|l|l|l|l|}
\hline & $\begin{array}{l}\text { Pupils with (at least } \\
\text { one) risky behaviour }\end{array}$ & $\begin{array}{l}\text { Pupils with no risky } \\
\text { behaviours }\end{array}$ & OR (95\% CI) \\
\hline Riots due to racial, ethnic or religious differences & $21 . .4 \%$ & $19.0 \%$ & $1.159(0.608-2.211)$ \\
\hline $\begin{array}{l}\text { Mess, rubbish, broken glass in the streets, pavements, } \\
\text { courtyards }\end{array}$ & $55.7 \%$ & $37.7 \%$ & $2.076(1.221-3.532)$ \\
\hline Drugs or excessive alcohol consumption & $44.3 \%$ & $46.2 \%$ & $0.927(0.547-1.573)$ \\
\hline Violence, vandalism and criminality & $42.9 \%$ & $26.4 \%$ & $2.094(1.215-3.609)$ \\
\hline Heavy traffic, traffic jams & $35.7 \%$ & $35.5 \%$ & $1.008(0.583-1.744)$ \\
\hline $\begin{array}{l}\text { Abandoned and unmaintained properties in the } \\
\text { surroundings }\end{array}$ & $17.1 \%$ & $23.4 \%$ & $0.676(0.342-1.336)$ \\
\hline Bad environment and lack of green spaces & $22.9 \%$ & $27.1 \%$ & $0.797(0.429-1.479)$ \\
\hline Lack of playgrounds and other sports grounds & $17.1 \%$ & $19.4 \%$ & $0.859(0.431-1.712)$ \\
\hline
\end{tabular}

Source: Own research

\section{Discussion}

Factors that impact substance abuse are divided into risky and protective categories (Jessor, 1991; Brooks et al., 2012; Dzúrová et al., 2015). They occur at the individual (e.g. gender, age, lifestyle, value orientation etc.) and spatial levels (e.g. quality and structure of the family environment, the school environment and perception, the influence of the group in which a person exists, cultural patterns and regulations of given social groups etc.). Additionally, there are other conditionalities of risky behaviors that belong to the group of "geographical factors" with a focus on the quality of the youth home environment and schools that pupils attend.

Multiple use of addictive substances does not have a uniform and stable definition in the scientific literature, and the methodological procedure of how to work with the relevant concept and how to measure it is not uniform as well (Dzúrová et al., 2015). Authors use in their studies either indicators of the number or amount of substances used simultaneously, from which they subsequently form various indices. Further, they examine the age of an individual at which he/she experiments 
with addictive substances and try to find out what circumstances determine such behavior (Kokkevi, 2012). R. Jessor (1994) defined the syndrome of the so-called risky behavior in his studies in the early 1990s. According to him, such behavior manifests itself in several forms, often mutually intertwining.

In our study, we examined the influence of various potential risk factors on three groups of substance abuse: alcohol, tobacco and marijuana. In the Czech Republic, it is not allowed to sell alcohol and tobacco to people under the age of 18 , it is possible to sell marijuana only on prescription and it is illegal to sell hashish. Still, a significant percentage of children and adolescents under the age of 18 have access to these substances, and some of them even use them regularly. Regulation of alcohol, tobacco and electronic cigarette consumption in the Czech Republic is one of the weakest in Europe. It is Germany that is the most liber$\mathrm{al}$ in indicators such as taxation, sales restrictions and advertising according to The Nanny State Index (2021). Low regulation is directly related to the availability of these substances among (not only) adolescents. As a result, alcohol and tobacco are more affordable for pupils in our country than in countries where the article is far more expensive due to high taxation. According to the ESPAD's (2020) survey carried out in 35 European countries in $2019,60 \%$ of respondents report the availability of tobacco as "pretty easy" or "very easy", $78 \%$ of respondents report the availability of alcohol and 32\% of respondents report the availability of marijuana. In the Czech Republic, however, the availability of these substances is considered even higher $-71 \%$ of respondents report tobacco availability as "pretty easy" or "very easy", $88 \%$ report alcohol availability and $47 \%$ report marijuana availability. According to these facts, we can say that the Czech Republic belongs to the countries where the prevalence of these substances abuse by adolescents is rather high. At the same time, however, it is evident that the high consumption is caused not only by their availabilities. In our questionnaire, we also asked about specific sources of risky substances, however this question was not obligatory and not all respondents answered it. Almost $60 \%$ of high-risk users answered the question "Where do you get alcohol from?" that they got it from their siblings or friends and $45 \%$ bought it themselves in a shop or restaurant. About 16\% of respondents got alcohol from their parents. Considering the fact that these are only risky users and that the socalled occasional drinking (small toasts at family celebrations and similar social events) is not reflected, this fact is for consideration.

The attitudes of the pupils declared in the questionnaire should be seen with the knowledge that not everyone had to tell the truth in all questions. This is one of the usual limitations of questionnaires, in that electronically filled questionnaires do not differ from paper ones. For a possible further research it would be good to extend it by interviewing students, but in our case this was already beyond the scope of the research. In our case, we used the Google Forms tool. This method offers some advantages over paper questionnaires, such as simpler and faster processing of the results or the possibility to make some questions mandatory. On the other hand, as with paper questionnaires, there is the possibility of students discussing among themselves what they fill in. The fact that students might have technical problems with the questionnaires and not know how to fill them in has not been confirmed in practice. Students also managed to complete the questionnaire during the class period (45 minutes) without any problems.

Our survey shows that pupils who behave risky as for alcohol, tobacco or marijuana consumption like going to school far less than students who do not behave so. There is an inverse proportion - the more addictive substance they use, the less they like to go to school. This may also be related to relationships that children have with their classmates and friends at schools, the way how their friends behave and especially, whether they also behave risky as for substance abuse. When a pupil gets "bored" at school, he/she is not motivated enough to study, which may be one of the reasons for "playing hooky". Thus, they may experiment with alcohol, tobacco or marijuana. They can be even more encouraged to do so by their classmates or friends with the same motivation, they can also get addictive substances from them or together with them, so these substances are easily available to them. Dvořáková (2006) mentioned that mainly boys adopt behavioral patterns from their older classmates- "bucks", who play hooky, or from former pupils, who gather in the vicinity of schools and consume alcohol and cigarettes. Problem children from schools join such gangs and then experiment with alcohol and cigarettes as well. On the other hand, if a pupil has good relationships at school, he/ she receives support from his/her classmates and teachers and likes going to school, which can have a positive impact on them in many ways. As Resnick et al. (1997) pointed out, pupils who have good relationships with their teachers are less likely to use alcohol and drugs than those who do not have close relationships with their teachers. A good teacher can play an important role in preventing addictive substance use. If children trust their teacher, they will also believe more easily that they should not use such substances.

Ideally, children should always feel safe at school. If children feel safe at school only sometimes, rarely or even never, it is completely unacceptable and it is necessary to find the causes and make changes. If pupils feel "mostly" safe at school, it can be caused, ac- 
cording to them, by a trouble, such as poor relationships with classmates and, in extreme cases, bullying or other inter-social problems, which can lead to a higher risk of substance abuse. And that is why the respondents who answer that they "usually" feel safe at school are more likely to behave risky.

Another important factor can be the child's family environment and relationships - if parents (or other family members with whom a pupil grows up) can motivate their children to like going to school, such children are less likely to use addictive substances. If a family does not offer a good environment for raising a child or if parents pay little attention to their preschool child, he/she may lag behind their classmates after entering the first year of elementary school. If such a negative issue is not dealt with quickly, it is possible that school will stop being "entertainment" for the child and later it will lead to playing hooky and using addictive substances.

Regarding school surroundings, pupils consider mess and rubbish and also violence and vandalism in the surroundings of their schools as the main problems which mainly pupils with risky behaviors have to face. More than half of our respondents with risky behaviors reported mess and rubbish as problems, $43 \%$ reported violence and vandalism as problems. Even more of them considered drugs and alcohol as problems, however there was not a significant difference between perception of pupils with and without risky behaviors. Concerning other observed factors, there were no significant differences between pupils with and without risky behaviors as well. Results of research by D. Dzúrová et al. (2015) differ minimally from our research in this part. According to their research, pupils perceive the biggest problems around their school to be mess and rubbish, drugs and excessive alcohol consumption, as well as violence and vandalism. However, this research also brings an interesting comparison of the prevalence of risk factors and risk behavior syndrome by school surroundings characteristics. In the case of the proportion of green spaces around the school, there is an inverse relationship in terms of the risk of cigarette or marijuana use, i.e. the more green spaces around the school, the less students use these substances at risk. However, this is not the case for alcohol and the dependence is also not clear for the amount of traffic around the school.
Pupils with at least one risky behavior reported less satisfaction with their schools than their classmates with no risky behaviors, namely in 6 out of 8 aspects, in 2 remaining aspects the percentage of pupils who are not satisfied with their school was almost the same in both categories. It seems that risky behaviors occur if pupils are not satisfied with their schools (both school attendance and school building), but the home environment is reported by those pupils as in the rest of a sample. Generally, pupils reported their home environments and the surroundings as better than their school environments and the surroundings, both pupils with and without risky behaviors. Differences in percentages of dissatisfied pupils were smaller concerning school and home environments than concerning buildings themselves.

Regarding individual aspects of places of residence and their surroundings, pupils with no risky behaviors were again more satisfied - they mostly reported their places of residence as very good to live and they always feel safe in the surroundings of their homes. The research has shown that pupils living in new detached houses belong to the category of the most risk factors. On the contrary, pupils living in terraced houses belonged to the category of the least probability on any risky behavior (there were even pupils who have never behaved risky). Respondents living in terraced houses were the least likely to use addictive substances - both overall and also for each risky substance. There were significant differences - while only $2 \%$ of respondents living in terraced houses are risky tobacco users, respondents living in new detached houses make up only $18 \%$. The same goes for alcohol which is used at-risk by $6 \%$ of pupils living in terraced houses and $21 \%$ of pupils living in new detached houses. Both those findings may be related to the fact that the financial situation of people living in new detached house in Prague and Brno, regarding current real estate prices, is better than of people living in terraced houses (which are often old), and also children who live there have more money that they can spend on addictive substances. In this respect, not only the housing development structure was important, but also the fact that the study was carried out in large cities. In smaller towns, housing development structure is different (e.g. more terraced houses, different prices of buildings, etc.) and the situation may be diverse.

\section{Conclusion}

Although the numbers of alcohol, tobacco and marijuana users among Czech teenagers are high, according to the ESPAD (2020) research there have been some positive trends in the past years. The number of teenage Czech smokers aged 15 is declining, and the same trend is among alcohol and marijuana users. Some sub-indicators, such as the prevalence of high regular consumption of spirits or wine, have stagnat- 
ed or increased slightly, but, according to these data, the overall development is favorable. This is probably related not only to legislative changes and price increase but also to changes in social perceptions of addictive substances. Many people have stopped considering particularly alcohol and tobacco as standard parts of their lives, and as advertisements for these substances and their featuring e.g. in movies have been limited, young people do not have such a need of using them. However, the subjective perception of the availability of most of these substances, which has been very high in the Czech Republic for a long time, has not declined yet.

In conclusion, we can say that some results of our study support the possibility of a relation between at-risk alcohol, tobacco and marijuana consump- tion and a place of residence, respectively a place of school. Therefore, we do think that both parents and school representatives, but also local government representatives at the municipal level (city district) should pay due attention to both the quality of housing developments and the school environment and the surroundings in order to prevent this undesirable issue. The results of our study are in accordance with the previous findings in the study carried out by the team led by prof. Dzúrová, which states that great attention should be paid to the urban renewal and redevelopment projects focusing on economic, physical, but also social renewal of specific parts of a city. We all know the positive benefits of such investments in health, quality of life and health inequalities (e.g. Dzúrová et al., 2015).

\section{References}

Brooks, F. M., Magnusson, J., Spencer, N., \& Morgan, A. (2012). Adolescent multiple risk behaviour: an asset approach to the role of family, school and community. Journal of public health, 34(suppl_1), i48-i56. DOI: 10.1093/pubmed/fds001

Cohen, D. A., Inagami, S., \& Finch, B. (2008). The built environment and collective efficacy. Health \& place, 14(2), 198-208. DOI: 10.1016/j.healthplace.2007.06.001

Csémy, L., Dvořáková, Z., Fialová, A., Kodl, M., Skývová, M. (2019). Užívání tabáku a alkoholu v České republice 2018, Report. Praha: SZÚ. http:// www.szu.cz/uploads/documents/szu/aktual/uzivani tabaku alkoholu cr 2018.pdf

Duncan, G.A. (2002). Beyond love: A critical race ethnography of the schooling of adolescent Black males. Equity \& excellence in education, 35(2), 131143. DOI: $10.1080 / 713845286$

Dvořáková, M. (2006). Obtíže se školní docházkou a záškoláctví na II. stupni základní školy [online]. Brno, 2006 [cit. 2021-05-03]. Available at: https:// is.muni.cz/th/xq2j0/.

Dzúrová, D., Csémy, L., Spilková, J., \& Lustigová, M. (2015).Zdravotně rizikové chování mládeže v Česku (1st ed.). Praha: SZÚ, 2015, ISBN: 9788070713433

Ensminger, M. E., Juon, H. S., \& Fothergill, K. E. (2002). Childhood and adolescent antecedents of substance use in adulthood. Addiction, 97(7), 833844. DOI: 10.1046/j.1360-0443.2002.00138.x

ESPAD (2020). ESPAD Report 2019: Results from the European School Survey Project on Alcohol and Other Drugs, EMCDDA Joint Publications, Publications Office of the European Union, Luxembourg. http://www.espad.org/espad-report-2019
Galán, I., Rodríguez-Blázquez, C., Simón, L., Ortiz, C., López-Cuadrado, T., \& Merlo, J. (2021). Small area influences on the individual unhealthy lifestyle behaviors: A multilevel analysis of discriminatory accuracy. Health \& Place, 67, 102506. DOI: 10.1016/j.healthplace.2021.102506

Handy, S. L., Boarnet, M. G., Ewing, R., \& Killingsworth, R. E. (2002). How the built environment affects physical activity: views from urban planning. American journal of preventive medicine, 23(2), 64-73. DOI: 10.1016/s0749-3797(02)00475-0

Hawkins, J. D., Catalano, R. F., \& Miller, J. Y. (1992). Risk and protective factors for alcohol and other drug problems in adolescence and early adulthood: implications for substance abuse prevention. Psychological bulletin, 112(1), 64. DOI: 10.1037/00332909.112.1.64

Jang, S. J., \& Johnson, B. R. (2001). Neighborhood disorder, individual religiosity, and adolescent use of illicit drugs: A test of multilevel hypotheses. Criminology, 39(1), 109-144. DOI: 10.1111/j.17459125.2001.tb00918.x

Jessor, R. (1991). Risk behavior in adolescence: A psychosocial framework for understanding and action. Journal of Adolescent Health, 12, 597-605. DOI: 10.1016/1054-139x(91)90007-k

Jessor, R., Donovan, J.E., \& Costa, F.M. (1994). Beyond adolescence - problem behavior and young adult development. $2^{\text {nd }}$ ed. Cambridge: Cambridge University Press, pp. 293. ISBN: 9780511878176

Kokkevi, A. (2012). Polydrug use by European adolescent. In Hibell et al. (Eds.). The 2011 ESPAD Report: Substance Use Among Students in 36 European Countries. Stockholm: The Swedish Council for 
Information on Alcohol and other Drugs, (p. 166170). DOI: $10.3109 / 09687630902806715$

Krieger, J., \& Higgins, D. L. (2002). Housing and health: time again for public health action. American journal of public health, 92(5), 758-768. DOI: 10.2105/ajph.92.5.758

Leatherdale, S. T., \& Manske, S. (2005). The relationship between student smoking in the school environment and smoking onset in elementary school students. Cancer Epidemiology and Prevention Biomarkers, 14(7), 1762-1765. DOI: 10.1158/1055-9965. EPI-05-0065

Newcomb, M.D. (1997). Psychosocial predictors and consequences of drag use: a developmental perspective within a prospective study. Journal of addictive diseases, 16(1), 51-89. DOI: 10.1300/J069v16n01_05

Resnick, M. D., Bearman, P. S., Blum, R. W., Bauman, K. E., Harris, K. M., Jones, J., ... \& Udry, J.R. (1997).
Protecting adoles cents from harm: findings from the National Longitudinal Study on Adolescent Health. Jama, 278(10), 823-832. DOI: 10.1001/ jama.278.10.823

Reynolds, A. J., Magro, S. W., Ou, S. R., \& Eales, L. (2019). Are parent involvement and school quality associated with adult smoking behaviors? Findings from an urban early childhood cohort. Preventive medicine, 127, 105768. DOI: 10.1016/j. ypmed.2019.105768

Spilková, J. (2015). Leisure time preferences and health-risk behavior of teenagers in the postcommunist Central European countries. Children's Geographies, 13(4), 435-450. DOI: 10.1080/14733285.2013.848742

The Nanny State Index 2021 (2021). Epicenter Network 2021. http://nannystateindex.org/ 